Review Article

\title{
Therapeutic Effects of Traditional Chinese Exercises on Musculoskeletal Pain: A Systematic Review and Meta-Analysis
}

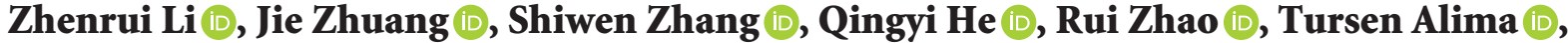 \\ and Lei Fang $(\mathbb{D}$
}

School of Rehabilitation Science, Shanghai University of Traditional Chinese Medicine, Shanghai 201203, China

Correspondence should be addressed to Lei Fang; fanglei586@126.com

Received 27 February 2021; Accepted 23 April 2021; Published 11 May 2021

Academic Editor: Xue-Qiang Wang

Copyright ( $\odot 2021$ Zhenrui Li et al. This is an open access article distributed under the Creative Commons Attribution License, which permits unrestricted use, distribution, and reproduction in any medium, provided the original work is properly cited.

\begin{abstract}
Background. The number of patients with musculoskeletal pain, which seriously affects people's quality of life, has increased. Traditional Chinese exercises are accepted and practiced to strengthen the body. Objective. This study aims to explore the efficacy of traditional Chinese exercises for the treatment of musculoskeletal pain. Methods. A comprehensive search of randomized controlled trials (RCTs) related to traditional Chinese exercises on patients with musculoskeletal pain was completed using PubMed, SinoMed, CNKI, VIP, and Wanfang Med Online databases. All RCTs published until February 2021 were considered. Two researchers independently screened the literature according to the predesigned inclusion and exclusion criteria, and data was extracted and assessed for their risk of bias via the Cochrane collaboration tool. Meta-analysis was performed using RevMan5.2 and Rx64 4.0.2 software. Results. A total of 45 RCT studies with 3178 patients were included. Traditional Chinese exercises were able to effectively alleviate patients with musculoskeletal pain $(\mathrm{MD}=-1.54,95 \%$ confidence interval $(-1.88,-1.19), P<0.01)$. Among them, the Yi Jin Jing exercise was superior to other exercises, while Wu Qin Xi showed no significant effects. Besides, traditional Chinese exercises had significant positive effects on the dysfunction and stiffness of the waist and knee joints. Traditional Chinese exercises could effectively relieve the clinical symptoms of patients with musculoskeletal pain. Particularly, the Yi Jin Jing exercise presented the most significant positive effect on pain reduction.
\end{abstract}

\section{Introduction}

Pain is an unpleasant feeling and emotional experience related to actual or potential tissue damage [1]. It is considered the fifth vital characteristic after breathing, heartbeat, blood pressure, and pulse [2]. Notably, chronic pain has to have an increased impact on human health $[3,4]$. In addition to causing physical pain, persistent pain can also cause emotional disorders such as anxiety and depression [5]. One of the most common forms of chronic pain is chronic musculoskeletal pain (CMP) [6], which is a chronic pain that occurs in soft tissues such as muscles, bones, joints, or tendons for more than three months $[7,8]$. This type of persistent pain is the most common symptom of musculoskeletal system diseases [9], and it accounts for the largest proportion of persistent pain in various regions and in all age groups [10]. CMP involves more than 150 diseases of the human motor system [6], which are closely related to degenerative changes, and can lead to suffering and disability in the elderly population $[11,12]$. Common CMPs include chronic low back pain, chronic osteoarthritis, osteoporosis, fibromyalgia syndrome, and myofascial pain syndrome [13]. About one-third of the world's population suffers from pain in the musculoskeletal system [14-16]. People in the age group from 45 to 64 years old have a higher incidence of CMP than people over $65[14,17]$, being the incidence in women higher than in men [12].

At present, the treatments for CMP include drug therapy, psychotherapy, and physical therapy. Drug therapy is the primary treatment, mainly using nonsteroidal anti-inflammatory analgesics, acetaminophen, tramadol, and other analgesics combined with antidepressants $[13,18]$. However, there are many disadvantages in the conventional treatment model of chronic pain, such as severe side effects and poor 
Identied studies from the databases using keywords and bibiographies of relevant articles $(N=5878)$ : PubMed $(N=395)$, CNKI $(N=4802)$, Wanfang Data $(N=263)$, SinoMed $(N=225)$, and CQVIP $(N=220)$

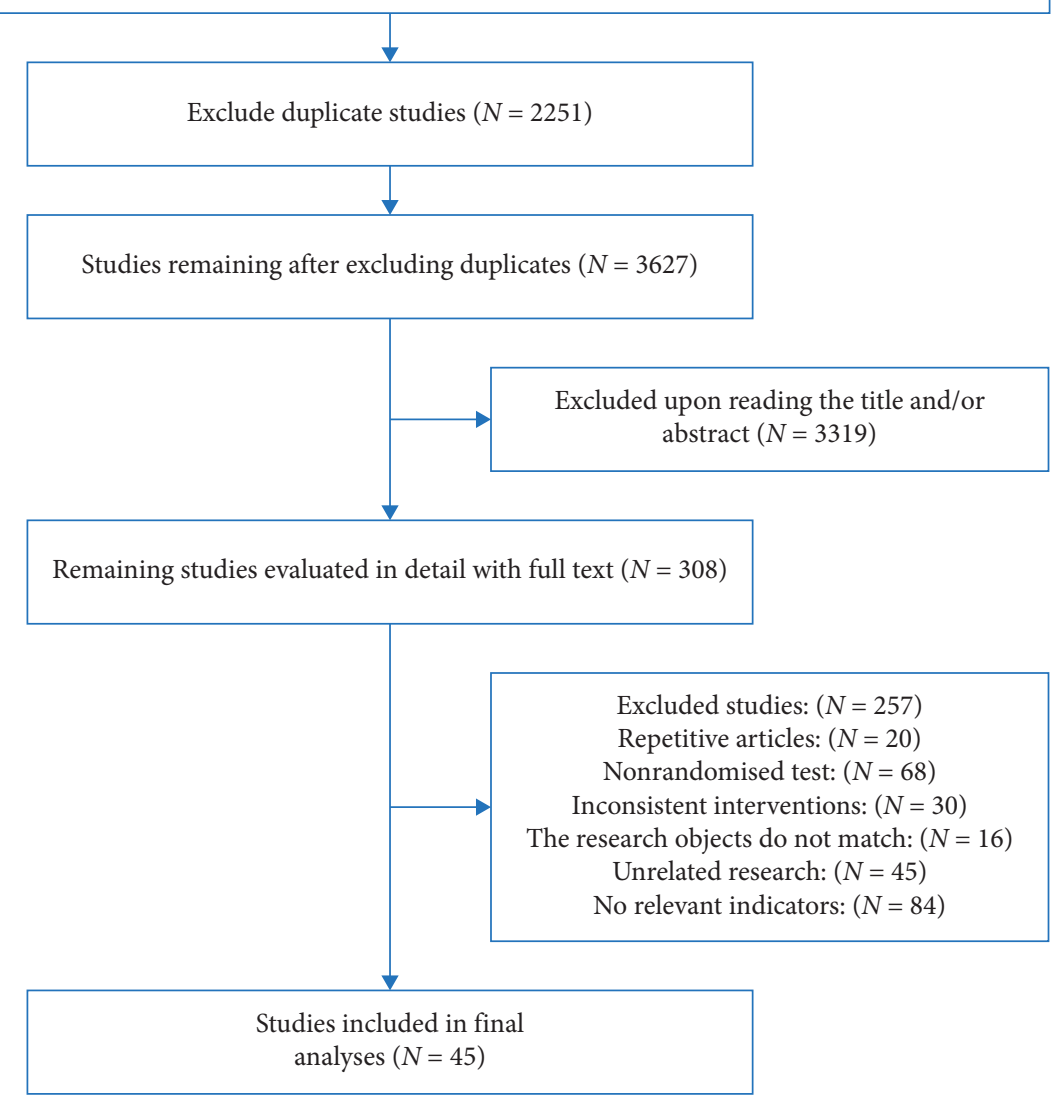

FIgURE 1: Document screening flow chart.

results, causing patients to seek alternative therapies and self-regulation measures, such as acupuncture, yoga, and biofeedback therapy [19]. Studies [20-23] show that traditional Chinese exercises have shown to have good results in CMP treatment. Traditional Chinese exercises mainly include Tai Chi, Wu Qin Xi, Ba Duan Jin, and Yi Jin Jing. These exercises are widely used to prevent and treat various chronic diseases, but there is a lack of systematic metaanalysis on traditional Chinese exercises in CMP treatment. This study systematically evaluates the efficacy of traditional Chinese exercises for CMP treatment, providing evidencebased information for the clinical application of traditional Chinese exercises for CMP.

\section{Materials and Methods}

2.1. Search Strategy and Article Selection. The two researchers independently conducted a comprehensive search on PubMed, SinoMed, CNKI, VIP, and Wanfang Med Online databases for studies using traditional exercises to treat musculoskeletal pain until February 2021, regardless of their language. The search terms used were ("Tai Chi" OR "Ba Duan Jin exercise" OR "Yi Jin Jing exercise" OR "Wu Qin Xi exercise") AND ("chronic low back pain" OR "knee osteoarthritis" OR "osteoporosis" OR "Fibromyalgia syndrome"). According to the characteristics of different databases, the subject words and free words were combined.

The preliminary screening was based on the title and abstract. Due to the wide range of interventions and diseases in these articles, only articles that included traditional Chinese exercises for musculoskeletal pain were considered. Two reviewers independently assessed the eligibility of these documents. When in disagreement, the two reviewers checked the full text of the article in question, and an agreement was only reached after discussion. After, an overall evaluation of the selected articles was made. Studies that met the following criteria were included in the study: (1) randomized controlled trials are included, (2) patients are adults with CMP, (3) the intervention type was by using traditional Chinese exercises, (4) peer-review publications are included, and (5) the difference between the experimental group and the control group's intervention is the use of traditional Chinese exercises, or the intervention method of the experimental group was the traditional Chinese exercises, and other therapies or standard therapies, or the intervention method of the control group was standard treatment or other therapies used in the experimental group besides the traditional Chinese exercises. If more than two groups in trials met the above criteria, the traditional Chinese exercise group was selected as the experimental 
TABLE 1: Basic characteristics of the included studies.

\begin{tabular}{|c|c|c|c|c|c|c|c|c|}
\hline \multirow[b]{2}{*}{ Study } & \multicolumn{2}{|c|}{ Example (person) } & \multicolumn{2}{|c|}{ Average age (y) } & \multicolumn{2}{|r|}{ Mode of intervention } & \multirow[b]{2}{*}{ Disease } & \multirow[b]{2}{*}{$\begin{array}{l}\text { Ending } \\
\text { indicator }\end{array}$} \\
\hline & $\begin{array}{l}\text { Experimental } \\
\text { group }\end{array}$ & $\begin{array}{l}\text { Control } \\
\text { group }\end{array}$ & $\begin{array}{l}\text { Experimental } \\
\text { group }\end{array}$ & $\begin{array}{c}\text { Control } \\
\text { group }\end{array}$ & $\begin{array}{l}\text { Test } \\
\text { group }\end{array}$ & Control group & & \\
\hline $\begin{array}{l}\text { Lee et al. } \\
{[25]}\end{array}$ & 29 & 15 & $70.2 \pm 4.8$ & $66.9 \pm 6.0$ & Tai Chi & No intervention & $\begin{array}{c}\text { Knee } \\
\text { osteoarthritis }\end{array}$ & (3) \\
\hline $\begin{array}{l}\text { Liu et al. } \\
{[26]}\end{array}$ & 15 & 15 & $58.13 \pm 5.38$ & $58.4 \pm 5.08$ & Tai Chi & Core stability training & Low back pain & (1) \\
\hline $\begin{array}{l}\text { Liu et al. } \\
{[26]}\end{array}$ & 15 & 13 & $58.13 \pm 5.38$ & $60.67 \pm 2.58$ & Tai Chi & No rehabilitation plan & Low back pain & (1) \\
\hline $\begin{array}{l}\text { Zhu et al. } \\
\text { [27] }\end{array}$ & 23 & 23 & $64.61 \pm 3.40$ & $64.53 \pm 3.43$ & Tai Chi & No rehabilitation plan & $\begin{array}{c}\text { Knee } \\
\text { osteoarthritis }\end{array}$ & (3) \\
\hline $\begin{array}{l}\text { Brismée } \\
\text { et al. [28] }\end{array}$ & 22 & 19 & $70.8 \pm 9.8$ & $68.8 \pm 8.9$ & Tai Chi & Health education & $\begin{array}{c}\text { Knee } \\
\text { osteoarthritis }\end{array}$ & (3) \\
\hline $\begin{array}{l}\text { Fransen } \\
\text { et al. [29] }\end{array}$ & 56 & 55 & $70.8 \pm 6.3$ & $69.6 \pm 6.1$ & Tai Chi & Spa course & $\begin{array}{c}\text { Knee } \\
\text { osteoarthritis }\end{array}$ & (3) \\
\hline $\begin{array}{l}\text { Fransen } \\
\text { et al. [29] }\end{array}$ & 56 & 41 & $70.8 \pm 6.3$ & $70.0 \pm 6.3$ & Tai Chi & None & $\begin{array}{c}\text { Knee } \\
\text { osteoarthritis }\end{array}$ & (3) \\
\hline $\begin{array}{l}\text { Wortley } \\
\text { et al. [30] }\end{array}$ & 15 & 9 & $69.5 \pm 6.7$ & $70.5 \pm 5.0$ & Tai Chi & $\begin{array}{l}\text { Open motion chain } \\
\text { resistance training }\end{array}$ & $\begin{array}{c}\text { Knee } \\
\text { osteoarthritis }\end{array}$ & (3) \\
\hline $\begin{array}{l}\text { Wortley } \\
\text { et al. [30] }\end{array}$ & 15 & 9 & $68.1 \pm 5.3$ & $70.5 \pm 5.0$ & Tai Chi & None & $\begin{array}{c}\text { Knee } \\
\text { osteoarthritis }\end{array}$ & (3) \\
\hline $\begin{array}{l}\text { Song et al. } \\
{[31]}\end{array}$ & 22 & 21 & $64.8 \pm 6.0$ & $62.5 \pm 5.6$ & Tai Chi & Conventional treatment & $\begin{array}{c}\text { Knee } \\
\text { osteoarthritis }\end{array}$ & (3) \\
\hline $\begin{array}{l}\mathrm{Xu} \text { and } \\
\text { Zhang } \\
{[32]}\end{array}$ & 83 & 85 & $21.05 \pm 1.15$ & $21.34 \pm 2.06$ & Tai Chi & None & Low back pain & (1) \\
\hline $\begin{array}{l}\text { Zhao et al. } \\
{[33]}\end{array}$ & 30 & 30 & $58.8 \pm 3.2$ & $60.1 \pm 2.8$ & Tai Chi & None & Osteoporosis & (1) \\
\hline $\begin{array}{l}\text { Zheng } \\
\text { et al. [34] }\end{array}$ & 40 & 40 & $66.25 \pm 6.01$ & $67.10 \pm 6.51$ & Tai Chi & Drug treatment & $\begin{array}{c}\text { Knee } \\
\text { osteoarthritis }\end{array}$ & (1) \\
\hline $\begin{array}{l}\text { Zhou } \\
\text { et al. [35] }\end{array}$ & 45 & 45 & 71.86 & 72.25 & Tai Chi & Drug treatment & Osteoporosis & (1) \\
\hline $\begin{array}{l}\text { Xu and } \\
\text { Tang [36] }\end{array}$ & 15 & 14 & $62.89 \pm 2.79$ & $63.47 \pm 2.85$ & Tai Chi & $\begin{array}{c}\text { Education and stretching } \\
\text { sessions and }\end{array}$ & $\begin{array}{c}\text { Knee } \\
\text { osteoarthritis }\end{array}$ & (3) \\
\hline Fan [37] & 20 & 20 & $55.7 \pm 8.64$ & $56.4 \pm 9.12$ & Tai Chi & Moxibustion & Low back pain & (1) \\
\hline $\begin{array}{l}\text { Tong et al. } \\
{[38]}\end{array}$ & 32 & 32 & $32.60 \pm 6.46$ & $32.66 \pm 6.53$ & Tai Chi & Sleep in a hard bed & Low back pain & (1) \\
\hline $\begin{array}{l}\text { An et al. } \\
{[39]}\end{array}$ & 14 & 14 & $65.4 \pm 8.2$ & $64.6 \pm 6.7$ & $\begin{array}{l}\text { Ba Duan } \\
\text { Jin } \\
\text { exercise }\end{array}$ & No intervention & $\begin{array}{c}\text { Knee } \\
\text { osteoarthritis }\end{array}$ & (3) \\
\hline $\begin{array}{l}\text { Ye et al. } \\
{[40]}\end{array}$ & 25 & 25 & $64.48 \pm 7.81$ & $63.08 \pm 3.65$ & $\begin{array}{l}\text { Ba Duan } \\
\text { Jin } \\
\text { exercise }\end{array}$ & Physical exercise & $\begin{array}{c}\text { Knee } \\
\text { osteoarthritis }\end{array}$ & (3) \\
\hline $\begin{array}{l}\text { Yang et al. } \\
\text { [41] }\end{array}$ & 40 & 40 & $54.20 \pm 13.30$ & $53.94 \pm 13.42$ & $\begin{array}{l}\text { Ba Duan } \\
\text { Jin } \\
\text { exercise }\end{array}$ & $\begin{array}{l}\text { Regular massage combined } \\
\text { with waist and dorsal } \\
\text { muscle exercise }\end{array}$ & Low back pain & (1) \\
\hline Chen [42] & 50 & 50 & $61.2 \pm 4.9$ & $60.8 \pm 5.8$ & $\begin{array}{l}\text { Ba Duan } \\
\text { Jin } \\
\text { exercise }\end{array}$ & Chinese medicinal diet & Osteoporosis & (1) \\
\hline $\begin{array}{l}\text { Chen } \\
\text { et al. [43] }\end{array}$ & 30 & 30 & $63.57 \pm 4.71$ & $62.27 \pm 4.66$ & $\begin{array}{l}\text { Ba Duan } \\
\text { Jin } \\
\text { exercise }\end{array}$ & $\begin{array}{l}\text { Rehabilitation } \\
\text { physiotherapy, health } \\
\text { education, strict sleeper } \\
\text { rigid bed, drug treatment }\end{array}$ & Osteoporosis & (1) \\
\hline $\begin{array}{l}\text { Du and } \\
\text { Zhao }[44]\end{array}$ & 40 & 40 & & & $\begin{array}{l}\text { Ba Duan } \\
\text { Jin } \\
\text { exercise }\end{array}$ & $\begin{array}{c}\text { Sodium alan } \\
\text { phosphate }+ \text { calcium agent } \\
\text { osteoporosis }\end{array}$ & Osteoporosis & (1) \\
\hline $\begin{array}{l}\mathrm{Li} \text { and } \\
\text { Feng [45] }\end{array}$ & 30 & 30 & $45.77 \pm 2.11$ & $46.38 \pm 2.33$ & $\begin{array}{l}\text { Ba Duan } \\
\text { Jin } \\
\text { exercise }\end{array}$ & SET therapy & Low back pain & (1) (2) \\
\hline $\begin{array}{l}\text { Liu et al. } \\
{[46]}\end{array}$ & 30 & 30 & $26.6 \pm 0.8$ & $27.3 \pm 1.1$ & $\begin{array}{l}\text { Ba Duan } \\
\text { Jin } \\
\text { exercise }\end{array}$ & General physiotherapy & Low back pain & (1) \\
\hline
\end{tabular}


TABle 1: Continued.

\begin{tabular}{|c|c|c|c|c|c|c|c|c|}
\hline \multirow[b]{2}{*}{ Study } & \multicolumn{2}{|c|}{ Example (person) } & \multicolumn{2}{|c|}{ Average age (y) } & \multicolumn{2}{|r|}{ Mode of intervention } & \multirow[b]{2}{*}{ Disease } & \multirow[b]{2}{*}{$\begin{array}{l}\text { Ending } \\
\text { indicator }\end{array}$} \\
\hline & $\begin{array}{l}\text { Experimental } \\
\text { group }\end{array}$ & $\begin{array}{l}\text { Control } \\
\text { group }\end{array}$ & $\begin{array}{l}\text { Experimental } \\
\text { group }\end{array}$ & $\begin{array}{c}\text { Control } \\
\text { group }\end{array}$ & $\begin{array}{l}\text { Test } \\
\text { group }\end{array}$ & Control group & & \\
\hline Liu [47] & 30 & 30 & $53.26 \pm 3.87$ & $53.47 \pm 3.61$ & $\begin{array}{l}\text { Ba Duan } \\
\text { Jin } \\
\text { exercise }\end{array}$ & Regular care & $\begin{array}{c}\text { Knee } \\
\text { osteoarthritis }\end{array}$ & (3) \\
\hline $\mathrm{Wu}[48]$ & 26 & 26 & $55.92 \pm 9.25$ & $56.46 \pm 9.13$ & $\begin{array}{l}\text { Ba Duan } \\
\text { Jin } \\
\text { exercise }\end{array}$ & $\begin{array}{l}\text { Intermediate } \\
\text { electrotherapy }\end{array}$ & Low back pain & (1) \\
\hline $\begin{array}{l}\text { Wang and } \\
\text { Zhao [49] }\end{array}$ & 52 & 51 & $46.51 \pm 4.31$ & $45.97 \pm 4.22$ & $\begin{array}{l}\text { Ba Duan } \\
\text { Jin } \\
\text { exercise }\end{array}$ & Rehabilitation training & Low back pain & (1) (2) \\
\hline $\begin{array}{l}\text { Wang } \\
\text { et al. [50] }\end{array}$ & 10 & 10 & $17.10 \pm 1.20$ & $17.60 \pm 1.08$ & $\begin{array}{l}\text { Ba Duan } \\
\text { Jin } \\
\text { exercise }\end{array}$ & $\begin{array}{c}\text { Pure wormwood box } \\
\text { moxibustion + eight } \\
\text { brocades }\end{array}$ & Low back pain & (1) (2) \\
\hline $\begin{array}{l}\text { Wang } \\
\text { et al. [50] }\end{array}$ & 10 & 10 & $16.90 \pm 1.10$ & $17.60 \pm 1.08$ & $\begin{array}{l}\text { Ba Duan } \\
\text { Jin } \\
\text { exercise }\end{array}$ & $\begin{array}{c}\text { Auricular-plaster } \\
\text { therapy }+ \text { pure wormwood } \\
\text { box moxibustion }\end{array}$ & Low back pain & (1) (2) \\
\hline $\begin{array}{l}\text { Wan et al. } \\
{[51]}\end{array}$ & 30 & 30 & $40.97 \pm 11.62$ & $42.87 \pm 10.87$ & $\begin{array}{l}\text { Ba Duan } \\
\text { Jin } \\
\text { exercise }\end{array}$ & Manipulation maneuver & $\begin{array}{l}\text { Fibromyalgia } \\
\text { syndrome }\end{array}$ & (1) \\
\hline $\begin{array}{l}\text { Su and } \\
\text { Deng [52] }\end{array}$ & 40 & 40 & $58.93 \pm 4.01$ & $59.12 \pm 3.88$ & $\begin{array}{l}\text { Ba Duan } \\
\text { Jin } \\
\text { exercise }\end{array}$ & Take medicine & Osteoporosis & (1) \\
\hline $\begin{array}{l}\text { Peng et al. } \\
\text { [53] }\end{array}$ & 47 & 44 & $68.49 \pm 4.68$ & $69.67 \pm 4.36$ & $\begin{array}{l}\text { Ba Duan } \\
\text { Jin } \\
\text { exercise }\end{array}$ & Take medicine & Osteoporosis & (1) \\
\hline $\begin{array}{l}\text { Pang et al. } \\
{[54]}\end{array}$ & 32 & 32 & $46.33 \pm 9.46$ & $47.25 \pm 8.43$ & $\begin{array}{l}\text { Ba Duan } \\
\text { Jin } \\
\text { exercise }\end{array}$ & Take medicine & Low back pain & (1) \\
\hline $\begin{array}{l}\text { Zheng } \\
\text { and } \\
\text { Cheng } \\
{[55]}\end{array}$ & 29 & 30 & $57.01 \pm 5.59$ & $58.63 \pm 5.07$ & $\begin{array}{l}\text { Ba Duan } \\
\text { Jin } \\
\text { exercise }\end{array}$ & Acupuncture treatment & $\begin{array}{c}\text { Knee } \\
\text { osteoarthritis }\end{array}$ & (1) (3) \\
\hline Yang [56] & 28 & 30 & $21.52 \pm 1.95$ & $20.41 \pm 2.09$ & $\begin{array}{l}\text { Yi Jin } \\
\text { Jing } \\
\text { exercise }\end{array}$ & None & Low back pain & (1) \\
\hline $\begin{array}{l}\text { Ye et al. } \\
{[57]}\end{array}$ & 26 & 26 & $60.83 \pm 9.52$ & $61.80 \pm 8.26$ & $\begin{array}{l}\text { Yi Jin } \\
\text { Jing } \\
\text { exercise }\end{array}$ & $\begin{array}{l}\text { Perkin ontology and } \\
\text { balance training }\end{array}$ & $\begin{array}{c}\text { Knee } \\
\text { osteoarthritis }\end{array}$ & (1) (3) \\
\hline $\begin{array}{l}\text { Zhao and } \\
\text { Zhang } \\
{[58]}\end{array}$ & 33 & 33 & $73.84 \pm 4.69$ & $72.94 \pm 5.97$ & $\begin{array}{l}\text { Yi Jin } \\
\text { Jing } \\
\text { exercise }\end{array}$ & $\begin{array}{l}\text { Western medicine } \\
\text { treatment }\end{array}$ & $\begin{array}{c}\text { Knee } \\
\text { osteoarthritis }\end{array}$ & (1) (3) \\
\hline $\begin{array}{l}\text { Zhao et al. } \\
\text { [59] }\end{array}$ & 45 & 45 & $64.00 \pm 8.97$ & $61.00 \pm 7.52$ & $\begin{array}{l}\text { Yi Jin } \\
\text { Jing } \\
\text { exercise }\end{array}$ & Inject sodium glassate & $\begin{array}{c}\text { Knee } \\
\text { osteoarthritis }\end{array}$ & (1) \\
\hline $\begin{array}{l}\text { Zhen et al. } \\
{[60]}\end{array}$ & 40 & 40 & & & $\begin{array}{l}\text { Yi Jin } \\
\text { Jing } \\
\text { exercise }\end{array}$ & Moxibustion & $\begin{array}{c}\text { Knee } \\
\text { osteoarthritis }\end{array}$ & (1) (3) \\
\hline $\begin{array}{l}\text { Zhen et al. } \\
{[60]}\end{array}$ & 40 & 40 & & & $\begin{array}{l}\text { Yi Jin } \\
\text { Jing } \\
\text { exercise }\end{array}$ & $\begin{array}{l}\text { Western medicine } \\
\text { treatment }\end{array}$ & $\begin{array}{c}\text { Knee } \\
\text { osteoarthritis }\end{array}$ & (1) (3) \\
\hline $\begin{array}{l}\text { Wu and } \\
\mathrm{Lu}[61]\end{array}$ & 45 & 45 & $54.56 \pm 10.07$ & $58.02 \pm 7.93$ & $\begin{array}{l}\text { Yi Jin } \\
\text { Jing } \\
\text { exercise }\end{array}$ & $\begin{array}{l}\text { Massage and intra-articular } \\
\text { ozone injection }\end{array}$ & $\begin{array}{c}\text { Knee } \\
\text { osteoarthritis }\end{array}$ & (1) (3) \\
\hline $\begin{array}{l}\text { Li et al. } \\
{[62]}\end{array}$ & 30 & 30 & & & $\begin{array}{l}\text { Yi Jin } \\
\text { Jing } \\
\text { exercise }\end{array}$ & $\begin{array}{c}\text { Massage manipulation } \\
\text { therapy }\end{array}$ & $\begin{array}{c}\text { Knee } \\
\text { osteoarthritis }\end{array}$ & (3) \\
\hline $\begin{array}{l}\text { Li et al. } \\
{[63]}\end{array}$ & 62 & 67 & $69.5 \pm 4.8$ & $69.3 \pm 4.5$ & $\begin{array}{l}\text { Yi Jin } \\
\text { Jing } \\
\text { exercise }\end{array}$ & Physiotherapy & $\begin{array}{c}\text { Knee } \\
\text { osteoarthritis }\end{array}$ & (1) (3) \\
\hline
\end{tabular}


TABLE 1: Continued.

\begin{tabular}{|c|c|c|c|c|c|c|c|c|}
\hline \multirow[b]{2}{*}{ Study } & \multicolumn{2}{|c|}{ Example (person) } & \multicolumn{2}{|c|}{ Average age $(y)$} & \multicolumn{2}{|c|}{ Mode of intervention } & \multirow[b]{2}{*}{ Disease } & \multirow{2}{*}{$\begin{array}{l}\text { Ending } \\
\text { indicator }\end{array}$} \\
\hline & $\begin{array}{l}\text { Experimental } \\
\text { group }\end{array}$ & $\begin{array}{c}\text { Control } \\
\text { group }\end{array}$ & $\begin{array}{l}\text { Experimental } \\
\text { group }\end{array}$ & $\begin{array}{c}\text { Control } \\
\text { group }\end{array}$ & $\begin{array}{l}\text { Test } \\
\text { group }\end{array}$ & Control group & & \\
\hline $\begin{array}{l}\text { Xiao et al. } \\
{[64]}\end{array}$ & 34 & 34 & $70.7 \pm 9.36$ & $70.2 \pm 10.35$ & $\begin{array}{l}\text { Wu Qin } \\
\text { Xi } \\
\text { exercise }\end{array}$ & Rehabilitation treatment & $\begin{array}{c}\text { Knee } \\
\text { osteoarthritis }\end{array}$ & (3) \\
\hline $\begin{array}{l}\text { Zhang } \\
\text { et al. [65] }\end{array}$ & 21 & 21 & $52.90 \pm 10.57$ & $56.19 \pm 10.88$ & $\begin{array}{l}\text { Wu Qin } \\
\text { Xi } \\
\text { exercise }\end{array}$ & $\begin{array}{l}\text { Oral amitriptyline } \\
\text { hydrochloride tablets }\end{array}$ & $\begin{array}{l}\text { Fibromyalgia } \\
\text { syndrome }\end{array}$ & (1) \\
\hline $\begin{array}{l}\text { Lei et al. } \\
{[66]}\end{array}$ & 32 & 31 & $52.91 \pm 15.80$ & $53.88 \pm 14.17$ & $\begin{array}{l}\text { Wu Qin } \\
\text { Xi } \\
\text { exercise }\end{array}$ & Rehabilitation gymnastics & Low back pain & (1) \\
\hline $\begin{array}{l}\text { Ning et al. } \\
{[67]}\end{array}$ & 26 & 28 & $40.73 \pm 11.52$ & $42.13 \pm 11.18$ & $\begin{array}{l}\text { Wu Qin } \\
\text { Xi } \\
\text { exercise }\end{array}$ & $\begin{array}{c}\text { Nuclear myocardial force } \\
\text { training and five poultry } \\
\text { exercises }\end{array}$ & Low back pain & (1) (2) \\
\hline $\begin{array}{l}\text { Tang et al. } \\
{[68]}\end{array}$ & 30 & 30 & $60.36 \pm 4.73$ & $59.86 \pm 5.92$ & $\begin{array}{c}\text { Wu Qin } \\
\qquad \mathrm{Xi} \\
\text { exercise }\end{array}$ & $\begin{array}{l}\text { Massage combined with } \\
\text { isokinetic training }\end{array}$ & $\begin{array}{c}\text { Knee } \\
\text { osteoarthritis }\end{array}$ & (1) \\
\hline $\begin{array}{l}\text { Ping and } \\
\text { Liao [69] }\end{array}$ & 20 & 20 & & & $\begin{array}{l}\text { Wu Qin } \\
\text { Xi } \\
\text { exercise }\end{array}$ & Standing exercise & $\begin{array}{c}\text { Knee } \\
\text { osteoarthritis }\end{array}$ & (3) \\
\hline
\end{tabular}

Note: (1) VAS; (2) ODI; (3) WOMAC.

group and the nonacupuncture treatment group was considered the control group for one-to-many comparisons. Trials that met any of the following criteria are excluded: (1) duplicated publications, (2) non-RCT research, (3) unavailable full text or missing data, and (4) low-quality research [24].

2.2. Data Extraction and Quality Appraisal. Review 5.2 software was used for literature quality evaluation and Rx64 4.0.2 for data analysis. The main result was the visual analog scale (VAS). The weighted mean difference and 95\% confidence interval (CI) are used for analysis. When the mean difference between different studies was too significant, SMD was selected as the combined statistic. Significant heterogeneity between the studies was considered using the random-effects model, and $P<0.05$ was set as a significant difference. The funnel chart was used to identify publication bias. The symmetry of the funnel chart was evaluated by bias regression analysis. When asymmetric, trimming and filling methods were used to adjust the publication bias in the meta-analysis.

\section{Results}

3.1. Documents Selection. A total of 5878 articles were retrieved by searching the databases mentioned above. Finally, according to the inclusion and exclusion criteria, 45 studies [25-69] were included in this meta-analysis (Figure 1). All the included research intervention methods were based on traditional Chinese exercises. Among them, 14 studies [25-38] used Tai Chi, 17 studies used Ba Duan Jin exercise [39-55], eight studies [56-63] used Yi Jin Jing exercise, and six studies [64-69] used Wu Qin Xi exercise. In the same studies, 22 focused on knee osteoarthritis, 14 on low back pain, seven on osteoporosis, and two on fibromyalgia syndrome. All the included studies were randomized controlled trials. The characteristics and quality evaluation of the included studies are shown in Table 1 and Figure 2.

\subsection{Meta-Analysis results}

3.2.1. Visual Analog Scale (VAS) of Pain. A total of 28 RCT trials, which included 2239 patients, were analyzed. VAS scores of patients with musculoskeletal pain who intervened in the Chinese traditional exercise group were significantly lower than those in the control group $[\mathrm{MD}=-1.54,95 \% \mathrm{CI}$ $(-1.88,-1.19), P<0.01]$, as shown in Figure 3. According to the subgroup analysis based on the types of traditional exercises, Tai Chi, Ba Duan Jin exercises, and Yi Jin Jing exercise all presented significant therapeutic effects on the VAS score of patients with musculoskeletal pain. Among them, the Yi Jin Jing exercise showed the best therapeutic effect (Figure 4). The analysis between $\mathrm{Wu}$ Qin Xi exercise subgroups showed no statistical difference. Two studies $[66,67]$ treated the disease for low back pain within the subgroup, and one study [58] focused on knee osteoarthritis. According to the subgroup analysis based on the types of musculoskeletal pain diseases, the results show that traditional Chinese exercise therapy provided significant positive therapeutic effects on knee osteoarthritis, chronic low back pain, osteoporotic pain, and fibromyalgia. Among them, the treatment of osteoporosis pain provided the best results, as shown in Figure 5.

3.2.2. Oswestry Dysfunction Index (ODI) Score. Six studies, which included a total of 365 patients, were analyzed. The ODI scores of patients with musculoskeletal pain with the 


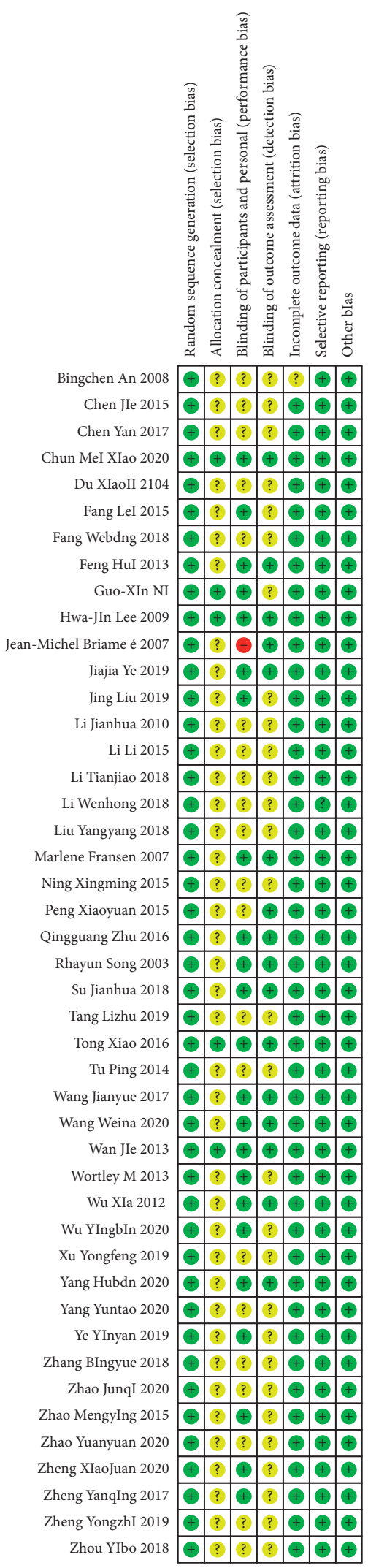

FIgURE 2: Bias risk assessment of included literature.

intervention of traditional Chinese exercise were significantly lower than those of the control group $[\mathrm{MD}=-2.73$, $95 \%$ CI $(-7.15,-1.69), P<0.01]$, as shown in Figure 6. The six studies were all related to low back pain. According to the subgroup analysis of the exercise type, the intervention effect of Yi Jin Jing exercise [56] was significantly better than that of Tai Chi [45, 48-50] and Wu Qin Xi exercise [67].

3.2.3. Western Ontario and McMaster University Osteoarthritis Index (WOMAC). A total of 17 studies were evaluated using WOMAC. Due to the large difference in the mean between the study groups, SMD combined statistics were selected. The results showed that traditional Chinese exercise was used to treat knee arthritis and was able to reduce WOMAC pain $[\mathrm{SMD}=-0.50,95 \%$ CI $(-0.75,-0.25)$, $P<0.01$ ], relieve joint WOMAC stiffness [SMD $=-0.37,95 \%$ CI $(-0.75,-0.00), P<0.01]$, and improve dysfunction $[\mathrm{SMD}=-0.57,95 \% \mathrm{CI}(-0.82,-0.32), P<0.01]$. All results were statistically significant, as shown in Figures 7-9. Besides, according to the type of exercise method, a subgroup analysis of WOMAC showed that the Ba Duan Jin exercise intervention was significantly better than other exercise methods in reducing pain and improving dysfunction. In contrast, the Yi Jin Jing exercise was superior to other exercises in improving joint stiffness.

3.2.4. Sensitivity Analysis. The sensitivity analyses of VAS exclude four studies with higher weights $[38,48,49,66]$, and the heterogeneity did not change significantly. The sensitivity analyses of ODI eliminate the two studies with higher weights $[55,56]$, and heterogeneity has changed significantly $\left(I^{2}=66 \%, T^{2}=6.4961, P=0.03\right)$, but the result does not change. Further analysis was done on two studies, and its heterogeneous sources may be related to the younger age of research subjects. Sensitivity analysis for WOMAC pain, excluding a study [46], reduced to moderate heterogeneity. Sensitivity analyses for WOMAC stiffness, WOMAC Physical Function, and Liu [47], Ye et al. [40], and Ye et al.'s [57] research studies were excluded. According to the Cochrane handbook [24], the three indicators are all reduced to moderate heterogeneity. The source of the articles' heterogeneity may relate to the low age of the included patients and the imbalance of the gender ratio between men and women.

3.2.5. Publication Bias. The results show that VAS was biased $(t=-3.2289, \mathrm{df}=29, P=0.003082)$, and the use of the trimming filling method to adjust the published bias resulted in statistically significant differences $(P<0.001)$, as seen in Figure 10. WOMAC index of the three-funnel chart and metabias regression analysis shows no publication bias. Furthermore, the reliability of this study was high.

\section{Discussion}

Traditional Chinese exercises have been widely used in clinics to prevent various diseases, improve the quality of life, and increase happiness [70]. The results of this study showed that Tai Chi, Yi Jin Jing exercise, and Ba Duan Jin exercise in traditional Chinese significantly reduced the pain 


\begin{tabular}{|c|c|c|c|c|c|c|c|c|c|c|}
\hline \multirow{2}{*}{ Study } & \multirow[b]{2}{*}{ Total } & \multicolumn{2}{|c|}{ Experimental } & \multicolumn{3}{|c|}{ Control } & \multirow{2}{*}{ Mean difference } & \multirow[b]{2}{*}{ MD } & \multirow{2}{*}{$95 \% \mathrm{CI}$} & \multirow{2}{*}{$\begin{array}{c}\text { Weight } \\
(\%)\end{array}$} \\
\hline & & Mean & SD & Total & Mean & SD & & & & \\
\hline Jing Liu 2019-1 & 15 & -2.20 & 0.9100 & 15 & -1.40 & 0.7600 & + & -0.80 & {$[-1.40 ;-0.20]$} & 3.3 \\
\hline Jing Liu 2019-2 & 15 & -2.20 & 0.9100 & 13 & 0.00 & 0.8500 & +1 & -2.20 & {$[-2.85 ;-1.55]$} & 3.3 \\
\hline Fan Weixing 2018 & 20 & -2.78 & 0.3700 & 20 & -1.95 & 0.3500 & + & -0.83 & {$[-1.05 ;-0.61]$} & 3.7 \\
\hline Tong Xiao 2016 & 32 & -5.24 & 1.0700 & 32 & -3.39 & 1.1300 & + & -1.85 & {$[-2.39 ;-1.31]$} & 3.4 \\
\hline Xu Yongfeng 2019 & 175 & -1.94 & 0.6800 & 175 & -0.02 & 0.8000 & + & -1.92 & {$[-2.08 ;-1.76]$} & 3.7 \\
\hline Zheng Yongzhi 2019 & 40 & -2.25 & 0.9800 & 40 & -1.15 & 0.9200 & + & -1.10 & {$[-1.52 ;-0.68]$} & 3.5 \\
\hline Jean-Michel Brisme é 2007 & 22 & -2.26 & 2.3700 & 19 & -0.79 & 1.7900 & + & -1.47 & {$[-2.75 ;-0.19]$} & 2.5 \\
\hline Zhou Yibo 2018 & 45 & -4.87 & 0.8800 & 45 & -2.38 & 1.0000 & + & -2.49 & {$[-2.88 ;-2.10]$} & 3.5 \\
\hline Zhao Mengying 2015 & 30 & -2.45 & 1.2500 & 30 & 0.02 & 1.1000 & + & -2.47 & {$[-3.07 ;-1.87]$} & 3.3 \\
\hline Peng Xiaoyuan 2015 & 47 & -3.00 & 1.3300 & 44 & -1.35 & 1.4100 & + & -1.65 & {$[-2.21 ;-1.09]$} & 3.4 \\
\hline Chen Jie 2015 & 50 & -1.60 & 0.0800 & 50 & -0.88 & 0.1100 & & -0.72 & {$[-0.76 ;-0.68]$} & 3.7 \\
\hline Du Xiaoli 2014 & 40 & -6.70 & 1.1500 & 40 & -6.11 & 1.3700 & & -0.59 & {$[-1.14 ;-0.04]$} & 3.4 \\
\hline Chen Yan 2017 & 30 & -6.11 & 1.3700 & 30 & -1.20 & 0.8100 & +1 & -4.91 & {$[-5.48 ;-4.34]$} & 3.4 \\
\hline Su Jianhua 2018 & 40 & -2.65 & 1.5300 & 40 & -2.20 & 1.6000 & $-1+$ & -0.45 & {$[-1.14 ; 0.24]$} & 3.2 \\
\hline Wan Jie 2013 & 30 & -5.67 & 1.0500 & 30 & -4.73 & 1.2600 & + & -0.94 & {$[-1.53 ;-0.35]$} & 3.4 \\
\hline Yang Yuntao 2020 & 38 & -2.79 & 1.1700 & 39 & -1.74 & 1.5400 & + & -1.05 & {$[-1.66 ;-0.44]$} & 3.3 \\
\hline Wang Weina 2020 & 52 & -4.06 & 1.3300 & 51 & -2.34 & 1.2100 & + & -1.72 & {$[-2.21 ;-1.23]$} & 3.5 \\
\hline Li Li 2015 & 30 & -3.74 & 1.2200 & 30 & -2.98 & 1.1400 & + & -0.76 & {$[-1.36 ;-0.16]$} & 3.3 \\
\hline Liu Wenhong 2018 & 30 & -2.97 & 1.4100 & 30 & -1.25 & 1.1900 & +1 & -1.72 & {$[-2.38 ;-1.06]$} & 3.3 \\
\hline Feng Hui 2013 & 32 & -3.36 & 2.6300 & 32 & -3.43 & 2.7000 & 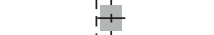 & 0.07 & {$[-1.24 ; 1.38]$} & 2.4 \\
\hline Wang Jianyue 2017-1 & 10 & -1.57 & 0.7600 & 10 & -0.51 & 0.6000 & + & -1.06 & {$[-1.66 ;-0.46]$} & 3.3 \\
\hline Wang Jianyue 2017-2 & 10 & -0.45 & 0.6000 & 10 & -0.51 & 0.6000 & & 0.06 & {$[-0.47 ; 0.59]$} & 3.4 \\
\hline Ye Yinyan 2019 & 26 & -2.76 & 1.2200 & 26 & -0.55 & 1.5800 & + & -2.21 & {$[-2.98 ;-1.44]$} & 3.1 \\
\hline Zhao Junqi 2020 & 33 & -4.76 & 1.0700 & 33 & -1.77 & 0.9400 & +1 & -2.99 & {$[-3.48 ;-2.50]$} & 3.5 \\
\hline Zhao Yuanyuan 2020 & 45 & -1.96 & 1.0900 & 45 & -1.23 & 1.1200 & + & -0.73 & {$[-1.19 ;-0.27]$} & 3.5 \\
\hline Zheng Yanqing 2017-1 & 40 & -5.78 & 1.3000 & 40 & -3.20 & 1.2000 & +1 & -2.58 & {$[-3.13 ;-2.03]$} & 3.4 \\
\hline Zheng Yanqing 2017-2 & 40 & -5.78 & 1.3000 & 40 & -1.40 & 1.3800 & $+i$ & -4.38 & {$[-4.97 ;-3.79]$} & 3.4 \\
\hline Fang Lei 2015 & 32 & -3.97 & 1.3200 & 31 & -2.90 & 1.9300 & + & -1.07 & {$[-1.89 ;-0.25]$} & 3.1 \\
\hline Ning Xingming 2015 & 26 & -3.81 & 1.3600 & 26 & -3.39 & 1.3100 & + & -0.42 & {$[-1.15 ; 0.31]$} & 3.2 \\
\hline Tang Lizhu 2019 & 28 & -4.42 & 0.8700 & 28 & -4.36 & 0.8900 & + & -0.06 & {$[-0.52 ; 0.40]$} & 3.5 \\
\hline Zhang Binigyue 2019 & 21 & -15.44 & 11.9000 & 21 & -3.76 & 11.6600 & $\begin{array}{rr}- & 1 \\
- & 1\end{array}$ & -11.68 & {$[-18.81 ;-4.55]$} & 0.2 \\
\hline Random effects model & 1124 & & & 1115 & & & $\Delta$ & -1.54 & {$[-1.88 ;-1.19]$} & 100.0 \\
\hline \multicolumn{7}{|c|}{ Heterogeneity: $I^{2}=97 \%, \tau^{2}=0.8463, p<0.01$} & $\begin{array}{llll}-10 & -5 & 0\end{array}$ & & & \\
\hline
\end{tabular}

FIGURE 3: Meta-analysis of the comparison of VAS between the traditional Chinese exercise group and the control group.

score of musculoskeletal diseases consistently across multiple meta-analysis studies [71-74]. Among musculoskeletal diseases, traditional Chinese exercise had the most significant impact on osteoporosis pain, which may be related to the cause of pain in each subordinate disease. Chronic low back pain, knee osteoarthritis, and fibromyalgia syndrome may be caused by noninfectious inflammation of joints. Therefore, proper traditional Chinese exercises are expected to relieve muscle spasms, prevent muscle strength decline [75], and relieve pain caused by inflammation.

Severe bone pain caused by osteoporosis, mainly due to the high bone turnover rate and increased bone resorption, leads to the destruction of bone microstructure. However, traditional Chinese exercise can improve bone biomechanics, regulating bone growth and development, promoting local blood circulation in bone, increasing bone cell activity, and reducing bone turnover and pain [52]. In the traditional Chinese exercise, Yi Jin Jing belongs to the group of high intensity of musculoskeletal strengthening exercises, and it is better than other traditional Chinese exercises for improving musculoskeletal diseases. However, there are only a few studies in this area. In analyzing the low back pain indicator ODI, traditional Chinese exercises play a significant therapeutic role. However, most studies are Tai Chi interventions on this indicator and could not distinguish the dominant types of exercises for the treatment of low back pain. For the intervention of knee arthritis, Tai Chi and $\mathrm{Ba}$ Duan Jin exercise had significantly positive effects on pain and stiffness in patients with knee arthritis, consistently with the results of previous studies by Xie et al. [74, 76-78]. However, the therapeutic effect of the Yi Jin Jing exercise was only noted for joint stiffness and dysfunction, while the Wu Qin Xi exercise did not present a significant therapeutic value on all the evaluated indicators.

These results can be further analyzed from the specific characteristics of each exercise. In the process of these exercises, for changes in body posture and shifting of the gravity center, Tai Chi and Ba Duan Jin exercise apply more pressure to the knee joint than the Yi Jin Jing exercise. Also, the sports characteristics of Tai Chi focus more on the coordination of various parts of the body, the speed, strength, flexibility, and others [79]. Therefore, Tai Chi is used to improving the balance ability in the elderly and preventing falls $[80,81]$. The Ba Duan Jin exercise comprises movements of holding the knees with hands, swinging the body, and moving the center of gravity, which is beneficial for multiangle and large-scale movement of the knee joint. Yi Jin Jing exercise mainly focuses on strengthening muscles and bones [82], and only a few movements are aimed at the knee joint. Although studies 


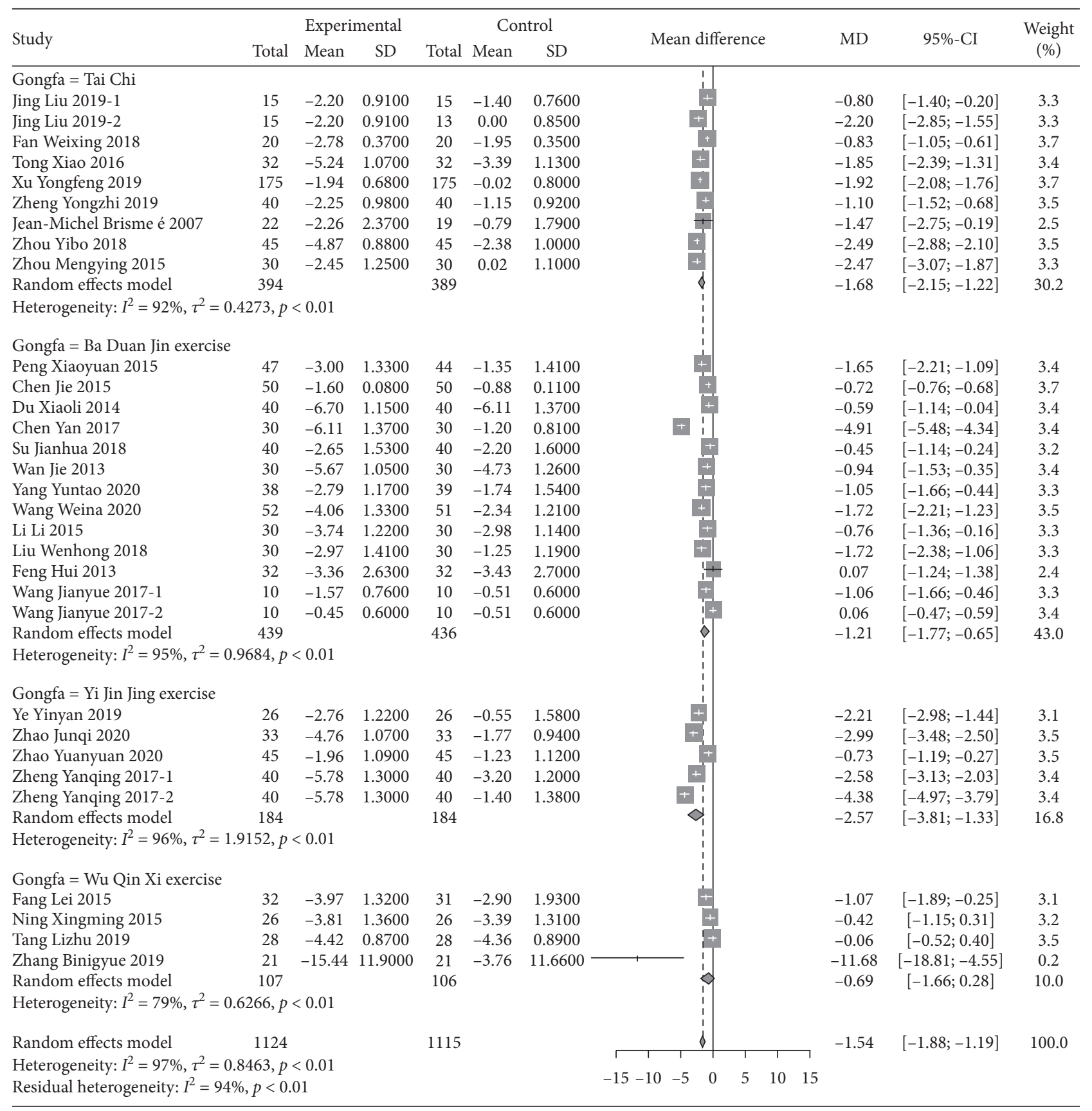

FIgURE 4: Subgroup analysis of different VAS comparisons.

have explored the effect of Yi Jin Jing exercise on the knee joint, the current research $[83,84]$ only has focused on the dysfunction and activity of the knee joint. However, we cannot ignore the possibility that the available literature may be scarce and include biased results. Wu Qin Xi exercise did not have a significant therapeutic effect on musculoskeletal pain. This may be related to the design purpose of the $\mathrm{Wu}$ Qin Xi exercise, which was to imitate the five movements of the tiger, deer, bear, ape, and bird to stretch and strengthen their body to prevent diseases [85]. Therefore, the intensity of intervention on the musculoskeletal part of the body is not as focused as traditional Chinese exercises.
Nonetheless, there are some limitations in our metaanalysis. Firstly, several uncontrollable variables of the patients, such as age and disease, may affect the results. Secondly, a few articles included in this review did not explicitly report the procedures for random sequence generation, allocation concealment, and the blinding of assessors. Hence, selection and detection biases may have affected the validity of our results. Finally, most of the participants in many research studies were elderly, which may contribute to a biased result. In the future, more RCTs that focused on the incidence of musculoskeletal pain in a specific age group may be needed to corroborate our results further. 


\begin{tabular}{|c|c|c|c|c|c|c|c|c|c|c|}
\hline \multirow{2}{*}{ Study } & \multicolumn{4}{|c|}{ Experimental } & \multicolumn{2}{|c|}{ Control } & \multirow[b]{2}{*}{ Mean difference } & \multirow{2}{*}{ MD } & \multirow{2}{*}{$95 \%$-CI } & \multirow{2}{*}{$\begin{array}{l}\text { Weight } \\
(\%)\end{array}$} \\
\hline & $\mathrm{T}_{\text {otal }}$ & Mean & SD & Total & Mean & SD & & & & \\
\hline \multicolumn{11}{|l|}{ Disease $=\mathrm{LBP}$} \\
\hline Fang Lei 2015 & 32 & -3.97 & 1.3200 & 31 & -2.90 & 1.9300 & & -1.07 & {$[-1.89 ;-0.25]$} & 3.1 \\
\hline Jing Liu 2019-1 & 15 & -2.20 & 0.9100 & 15 & -1.40 & 0.7600 & & -0.80 & {$[-1.40 ;-0.20]$} & 3.3 \\
\hline Jing Liu 2019-2 & 15 & -2.20 & 0.9100 & 13 & 0.00 & 0.8500 & + & -2.20 & {$[-2.85 ;-1.55]$} & 3.3 \\
\hline Fan Weixingl 2018 & 20 & -2.78 & 0.3700 & 20 & -1.95 & 0.3500 & & -0.83 & {$[-1.05 ;-0.61]$} & 3.7 \\
\hline Li Li 2015 & 30 & -3.74 & 1.2200 & 30 & -2.98 & 1.1400 & + & -0.76 & {$[-1.36 ;-0.16]$} & 3.3 \\
\hline Liu Wenhong 2018 & 30 & -2.97 & 1.4100 & 30 & -1.25 & 1.1900 & + & -1.72 & {$[-2.38 ;-1.06]$} & 3.3 \\
\hline Ning Xingmin 2015 & 26 & -3.81 & 1.3600 & 26 & -3.39 & 1.3100 & & -0.42 & {$[-1.15 ; 0.31]$} & 3.2 \\
\hline Feng Hui 2013 & 32 & -3.36 & 2.6300 & 32 & -3.43 & 2.7000 & $\frac{1}{4}$ & 0.07 & {$[-1.24 ; 1.38]$} & 2.4 \\
\hline Tong Xiao 2016 & 32 & -5.24 & 1.0700 & 32 & -3.39 & 1.1300 & +1 & -1.85 & {$[-2.39 ;-1.31]$} & 3.4 \\
\hline Wang Jianyue 2017-1 & 10 & -1.57 & 0.7600 & 10 & -0.51 & 0.6000 & +1 & -1.06 & {$[-1.66 ;-0.46]$} & 3.3 \\
\hline Wang Jianyue 2017-2 & 10 & -0.45 & 0.6000 & 10 & -0.51 & 0.6000 & 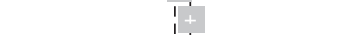 & 0.06 & {$[-0.47 ; 0.59]$} & 3.4 \\
\hline Wang Weina 2020 & 52 & -4.06 & 1.3300 & 51 & -2.34 & 1.2100 & + & -1.72 & {$[-2.21 ;-1.23]$} & 3.5 \\
\hline Xu Yongfeng 2019 & 175 & -1.94 & 0.6800 & 175 & -0.02 & 0.8000 & +1 & -1.92 & {$[-2.08 ;-1.76]$} & 3.7 \\
\hline Yang Yuntao 2020 & 38 & -2.79 & 1.1700 & 39 & -1.74 & 1.5400 & + & -1.05 & {$[-1.66 ;-0.44]$} & 3.3 \\
\hline Random effects model & 517 & & & 514 & & & $\widehat{\Delta}$ & -1.13 & {$[-1.52 ;-0.74]$} & 46.2 \\
\hline \multicolumn{11}{|c|}{ Heterogeneity: $I^{2}=90 \%, \tau^{2}=0.4516, p<0.01$} \\
\hline \multicolumn{11}{|l|}{ Disease $=\mathrm{KOA}$} \\
\hline Ye Yinyan 2019 & 26 & -2.76 & 1.2200 & 26 & -0.55 & 1.5800 & + & -2.21 & {$[-2.98 ;-1.44]$} & 3.1 \\
\hline Tang Lizhu 2019 & 28 & -4.42 & 0.8700 & 28 & -4.36 & 0.8900 & & -0.06 & {$[-0.52 ; 0.40]$} & 3.5 \\
\hline Zhao Junqi 2020 & 33 & -4.76 & 1.0700 & 33 & -1.77 & 0.9400 & $+!$ & -2.99 & {$[-3.48 ;-2.50]$} & 3.5 \\
\hline Zhao Yuanyuan 2020 & 45 & -1.96 & 1.0900 & 45 & -1.23 & 1.1200 & & -0.73 & {$[-1.19 ;-0.271$} & 3.5 \\
\hline Zheng Yangingi 2017-1 & 40 & -5.78 & 1.3000 & 40 & -3.20 & 1.2000 & +1 & -2.58 & {$[-3.13 ;-2.03]$} & 3.4 \\
\hline Zheng Yanqingi 2017-2 & 40 & -5.78 & 1.3000 & 40 & -1.40 & 1.3800 & +1 & -4.38 & {$[-4.97 ;-3.79]$} & 3.4 \\
\hline Zheng Yongzhi 2019 & 40 & -2.25 & 0.9800 & 40 & -1.15 & 0.9200 & + & -1.10 & {$[-1.52 ;-0.68]$} & 3.5 \\
\hline Jean-Michel Brisme é 2007 & 22 & -2.26 & 2.3700 & 19 & -0.79 & 1.7900 & + & -1.47 & {$[-2.75 ;-0.19]$} & 2.5 \\
\hline Random effects model & 274 & & & 271 & & & $\diamond$ & -1.94 & {$[-2.96 ;-0.93]$} & 26.3 \\
\hline \multicolumn{11}{|c|}{ Heterogeneity: $I^{2}=96 \%, \tau^{2}=2.0296, p<0.01$} \\
\hline \multicolumn{11}{|l|}{ Disease $=$ OP } \\
\hline Zhou Yibo 2018 & 45 & -4.87 & 0.8800 & 45 & -2.38 & 1.0000 & + & -2.49 & {$[-2.88 ;-2.10]$} & 3.5 \\
\hline Zhao Mengying 2015 & 30 & -2.45 & 1.2500 & 30 & 0.02 & 1.1000 & + & -2.47 & {$[-3.07 ;-1.87]$} & 3.3 \\
\hline Peng Xiaoyuan 2015 & 47 & -3.00 & 1.3300 & 44 & -1.35 & 1.4100 & + & -1.65 & {$[-2.21 ;-1.09]$} & 3.4 \\
\hline Su Jianhua 2018 & 40 & -2.65 & 1.5300 & 40 & -2.20 & 1.6000 & $\frac{1}{1}$ & -0.45 & {$[-1.14 ; 0.241$} & 3.2 \\
\hline Chen Jie 2015 & 50 & -1.60 & 0.0800 & 50 & -0.88 & 0.1100 & + & -0.72 & {$[-0.76 ;-0.68]$} & 3.7 \\
\hline Du Xiaoli 2014 & 40 & -6.70 & 1.1500 & 40 & -6.11 & 1.3700 & + & -0.59 & {$[-1.14 ;-0.04]$} & 3.4 \\
\hline Random effects model & 252 & & & 249 & & & $\diamond$ & -1.40 & {$[-2.17 ;-0.63]$} & 20.6 \\
\hline \multicolumn{11}{|c|}{ Heterogeneity: $I^{2}=96 \%, \tau^{2}=0.8621, p<0.01$} \\
\hline \multicolumn{11}{|l|}{ Disease $=\mathrm{FM}$} \\
\hline Chen Yan 2017 & 30 & -6.11 & 1.3700 & 30 & -1.20 & 0.8100 & +1 & -4.91 & {$[-5.48 ;-4.34]$} & 3.4 \\
\hline Zhang Bingyue 2019 & 21 & -15.44 & 11.9000 & 21 & -3.76 & 11.6600 & & -11.68 & {$[-18.81 ;-4.55]$} & 0.2 \\
\hline Wan Ji 2013 & 30 & -5.67 & 1.0500 & 30 & -4.73 & 1.2600 & & -0.94 & {$[-1.53 ;-0.35]$} & 3.4 \\
\hline Random effects model & 81 & & & 81 & & & $<$ & -4.34 & {$[-7.97 ;-0.70]$} & 6.9 \\
\hline \multicolumn{11}{|c|}{ Heterogeneity: $I^{2}=98 \%, \tau^{2}=8.1227, p<0.01$} \\
\hline Random effects model & 1124 & & & 1115 & & & 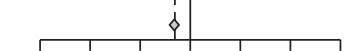 & -1.54 & {$[-1.88 ;-1.19]$} & 100.0 \\
\hline \multicolumn{7}{|c|}{$\begin{array}{l}\text { Heterogeneity: } I^{2}=97 \%, \tau^{2}=0.8463, p<0.01 \\
\text { Residual heterogeneity: } I^{2}=95 \%, p<0.01\end{array}$} & $-15-10-5$ & & & \\
\hline
\end{tabular}

FiguRE 5: Subgroup analysis of the comparison of pain VAS scores of different diseases.

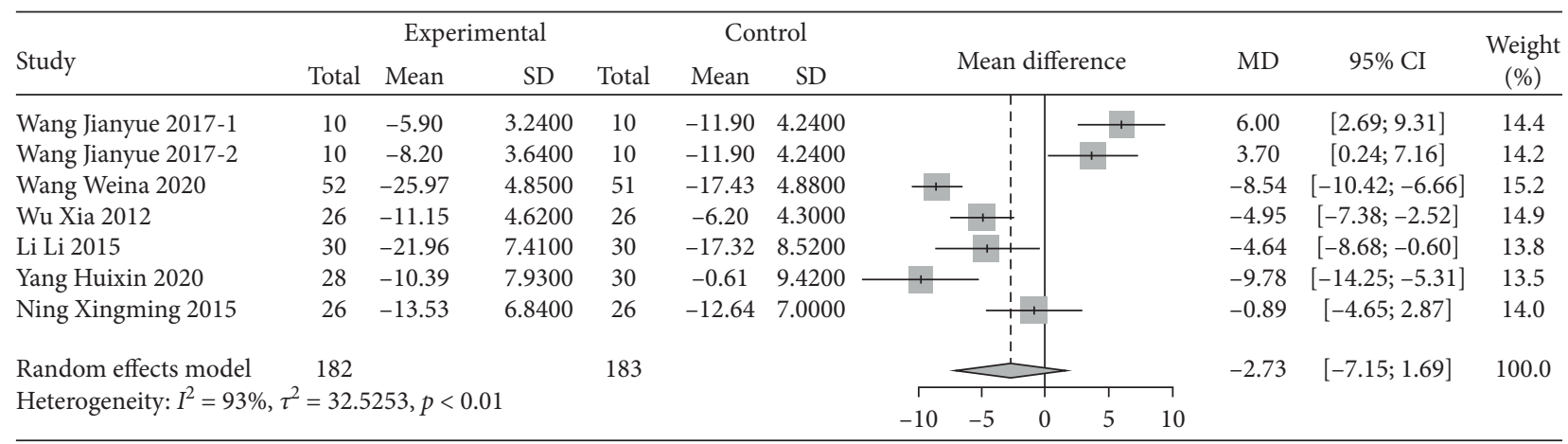

FIGURE 6: Meta-analysis of the comparison of ODI scores between the traditional Chinese exercise group and the control group. 


\begin{tabular}{|c|c|c|c|c|c|c|c|c|c|c|}
\hline \multirow{2}{*}{ Study } & \multirow[b]{2}{*}{ Total } & \multicolumn{2}{|c|}{ Experimental } & \multirow[b]{2}{*}{ Total } & \multicolumn{2}{|c|}{ Control } & \multirow{2}{*}{$\begin{array}{c}\text { Standardised mean } \\
\text { difference }\end{array}$} & \multirow{2}{*}{ SMD } & \multirow{2}{*}{$95 \%$ CI } & \multirow{2}{*}{$\begin{array}{c}\text { Weight } \\
(\%)\end{array}$} \\
\hline & & Mean & SD & & Mean & SD & & & & \\
\hline Hwa-Jin Lee 2009 & 29 & -0.70 & 3.8600 & 15 & 1.30 & 3.8600 & & -0.51 & {$[-1.14 ; 0.12]$} & 6.1 \\
\hline Jean-Michel Brisme é 2007 & 22 & -2.53 & 6.1900 & 19 & -0.93 & 4.9100 & & -2.28 & {$[-0.90 ; 0.34]$} & 6.2 \\
\hline Qingguang Zhu 2016 & 23 & -3.31 & 4.3200 & 23 & -0.28 & 5.4500 & & -0.61 & {$[-1.20 ;-0.01]$} & 6.4 \\
\hline Guo-Xin Ni 2010 & 14 & -1.35 & 0.3900 & 15 & 0.07 & 0.9300 & +1 & -1.91 & {$[-2.81 ;-1.01]$} & 4.4 \\
\hline Wortley M 2013-1 & 12 & -28.00 & 123.4100 & 13 & -84.00 & 105.3600 & + & 0.47 & {$[-0.32 ; 1.27]$} & 5.0 \\
\hline Wortley M 2013-2 & 12 & -28.00 & 123.4100 & 6 & -13.00 & 91.4100 & & -0.12 & {$[-1.11 ; 0.86]$} & 4.0 \\
\hline Rhayun Song 2003 & 22 & -2.45 & 3.9000 & 21 & 0.61 & 5.1000 & & -0.66 & {$[-1.28 ;-0.05]$} & 6.3 \\
\hline Marlene Fransen 2007-1 & 56 & -9.60 & 18.9500 & 55 & -10.90 & 18.0900 & & 0.07 & {$[-0.30 ; 0.44]$} & 8.2 \\
\hline Marlene Fransen 2007-2 & 56 & -9.60 & 18.9500 & 41 & -4.40 & 16.6100 & $\frac{1}{1+}$ & -0.29 & {$[-0.69 ; 0.12]$} & 7.9 \\
\hline Bingchen An 2008 & 14 & -78.90 & 105.2900 & 14 & 21.40 & 99.2000 & +1 & -0.95 & {$[-1.74 ;-0.16]$} & 5.1 \\
\hline Jiajia Ye 2020 & 25 & -2.96 & 5.2700 & 25 & -2.76 & 8.7200 & & -0.03 & {$[-0.58 ; 0.53]$} & 6.7 \\
\hline Liu Yangyang 2018 & 30 & -8.30 & 2.3300 & 30 & -4.67 & 2.4200 & $\longrightarrow \quad$ I & -1.51 & {$[-2.09 ;-0.93]$} & 6.5 \\
\hline Ye Yinyan 2019 & 26 & -4.50 & 2.0900 & 26 & -1.60 & 4.1600 & +1 & -0.87 & {$[-1.44 ;-0.30]$} & 6.6 \\
\hline Li Jianhua 2010 & 30 & -12.60 & 4.2100 & 30 & -10.33 & 7.5000 & $\frac{1}{1}$ & -0.37 & {$[-0.88 ; 0.14]$} & 7.1 \\
\hline Chun Mei Xiao 2020 & 34 & -2.80 & 3.6200 & 34 & -1.80 & 3.7200 & $\frac{1}{1+}$ & -0.27 & {$[-0.75 ; 0.21]$} & 7.3 \\
\hline Tu Ping 2014 & 20 & -1.70 & 1.6400 & 20 & -0.75 & 1.6300 & & -0.57 & {$[-1.20 ; 0.06]$} & 6.1 \\
\hline Random effects model & 425 & & & 387 & & & 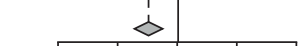 & -0.50 & {$[-0.75 ;-0.25]$} & 100.0 \\
\hline \multicolumn{7}{|c|}{ Heterogeneity: $I^{2}=66 \%, \tau^{2}=0.1678, p<0.01$} & -2 & & & \\
\hline
\end{tabular}

FIGURE 7: Meta-analysis of WOMAC pain comparison between the traditional Chinese exercise group and the control group.

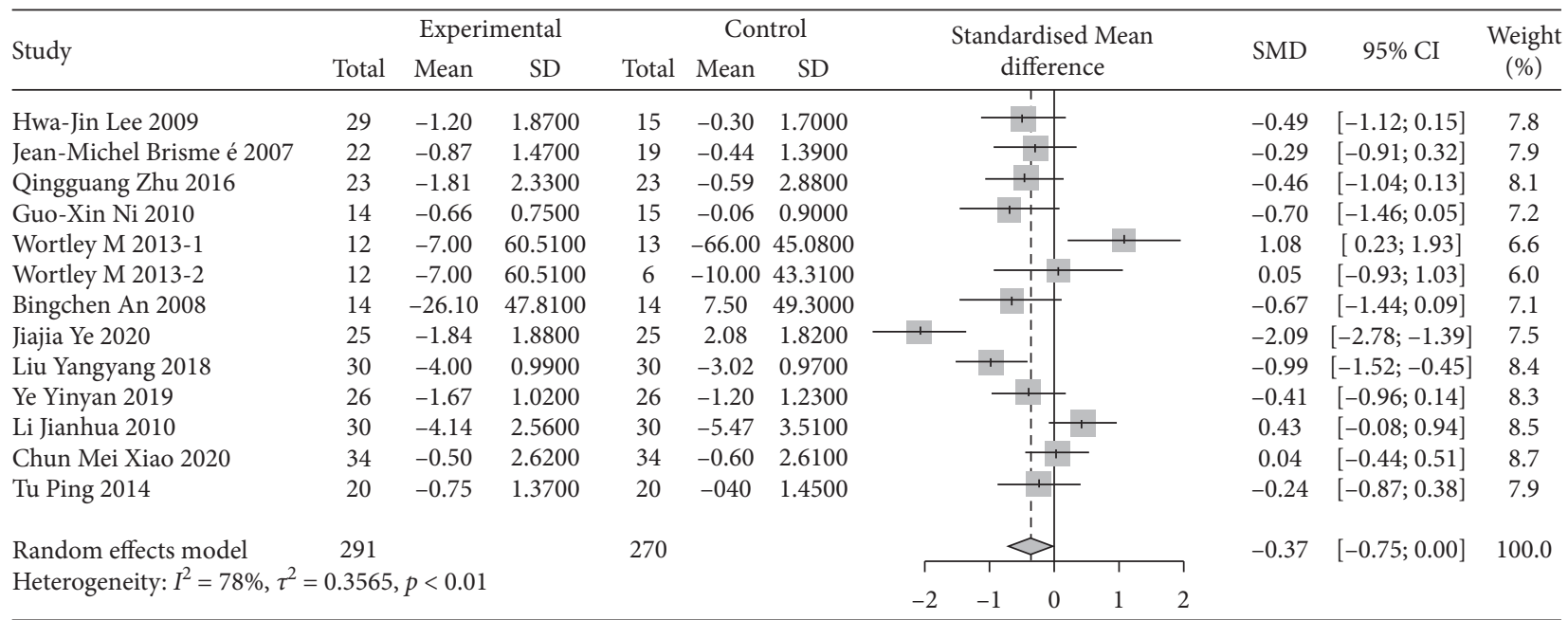

Figure 8: Meta-analysis of WOMAC stiffness comparison between the traditional Chinese exercise group and the control group.

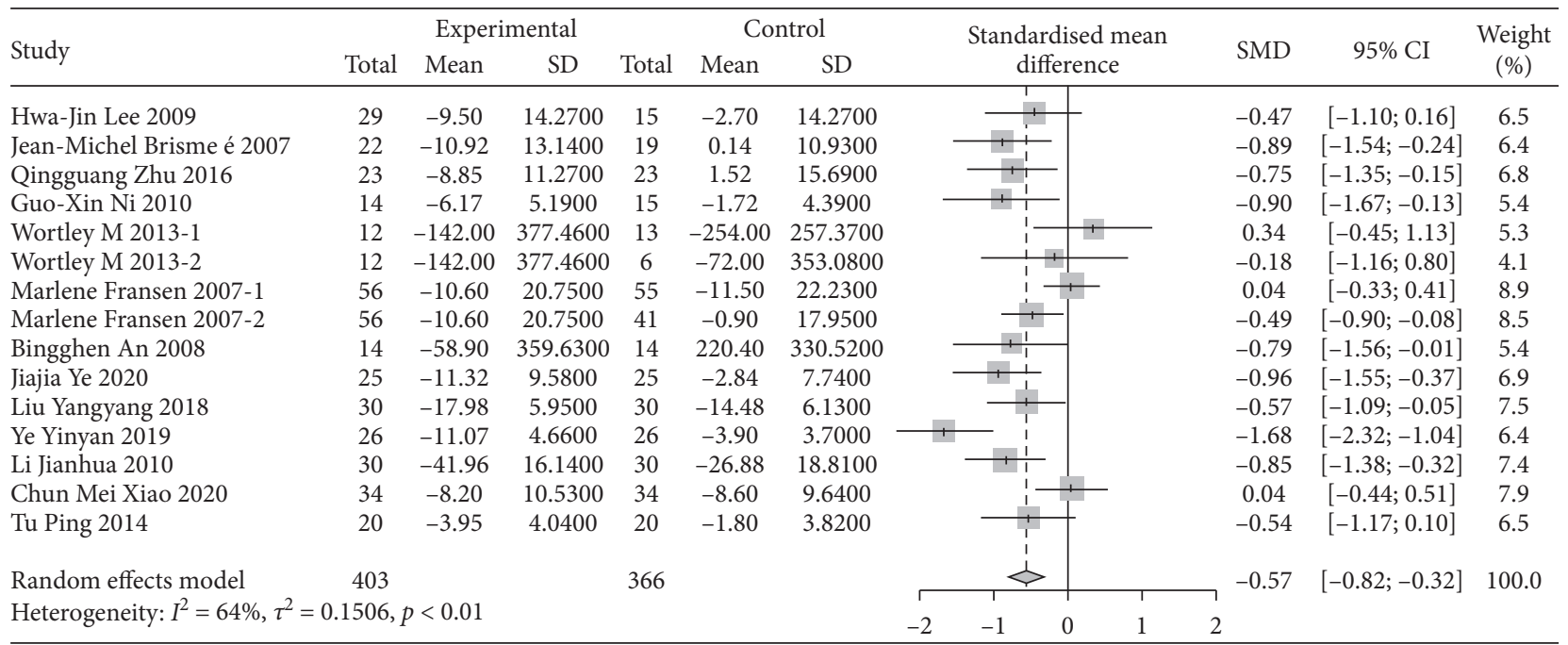

Figure 9: Meta-analysis of WOMAC physical function comparison between traditional Chinese exercise group and control group. 


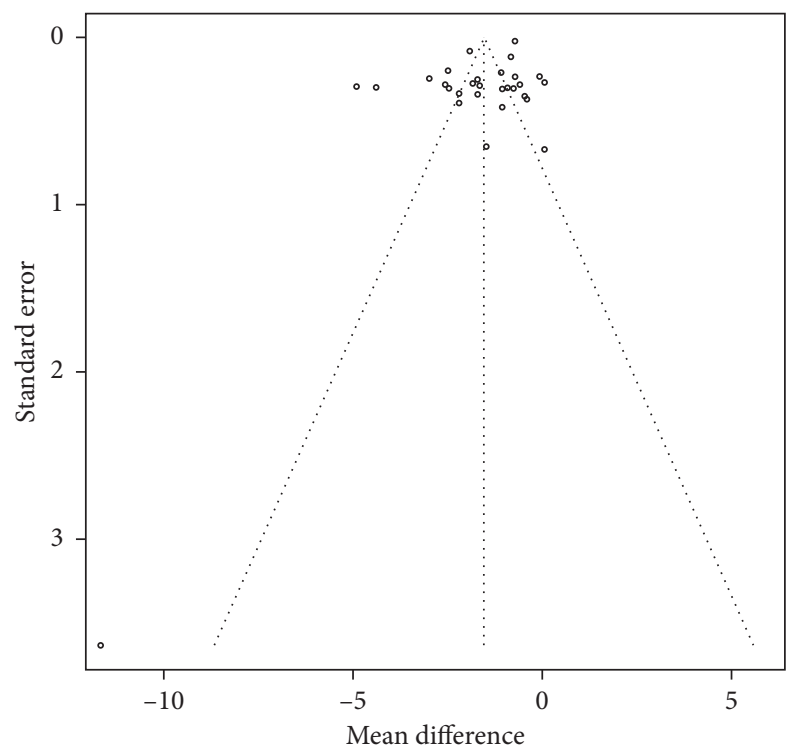

(a)

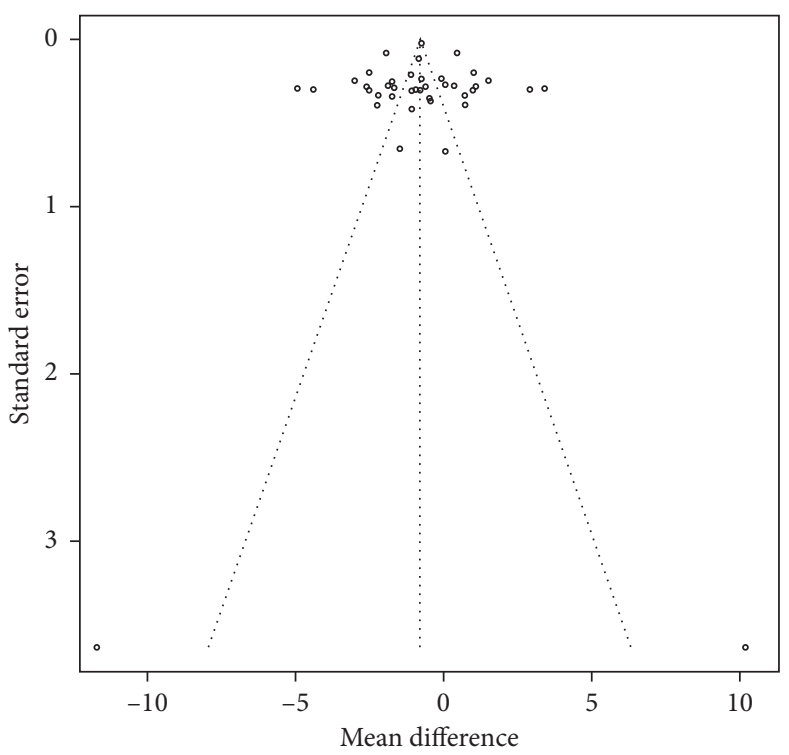

(b)

Figure 10: The funnel plots of VAS.

\section{Conclusion}

The traditional Chinese therapeutic exercises provided a more significant improvement effect on VAS, ODI, and WOMAC scores, with the Yi Jin Jing exercise being the best exercise in changing VAS. The Ba Duan Jin exercise was the most impactful in treating joint stiffness. However, additional large-sample studies with strict designs are needed to prove the therapeutic effects of different traditional Chinese exercises in CMP patients.

\section{Data Availability}

The data used to support the findings of this study are available on request from the corresponding author.

\section{Conflicts of Interest}

The authors declare that they have no conflicts of interest.

\section{Authors' Contributions}

Lei Fang conceived the review. Zhenrui Li drafted the protocol and searched the literature to identify eligible trials, extracted and analyzed data, and drafted the manuscript. Jie Zhuang, Shiwen Zhang, and Qingyi He did searches to identify eligible trials and revised the tables in the drafted manuscript. Rui Zhao and Alima Tursen revised and commented on the drafted protocol and manuscript. All authors approved the final manuscript. Zhenrui Li and Jie Zhuang contributed equally to this work.

\section{Acknowledgments}

The authors thank all the participants and clinical researchers involved in the publications cited in this review and peer reviewers who contributed to the continuous improvement of this article.

\section{References}

[1] S. N. Raja, D. B. Carr, M. Cohen et al., "The revised international association for the Study of Pain definition of pain: concepts, challenges, and compromises," Pain, vol. 161, no. 9, pp. 1976-1982, 2020.

[2] A. C. D. C. Williams and K. D. Craig, "Updating the definition of pain," Pain, vol. 157, no. 11, pp. 2420-2423, 2016.

[3] A. May, "Chronic pain may change the structure of the brain," Pain, vol. 137, no. 1, pp. 7-15, 2008.

[4] B. J. Sessle, "The pain crisis: what it is and what can be done," Pain Research and Treatment, vol. 2012, Article ID 703947 , 6 pages, 2012.

[5] E. Xu, S. S. Li, C. W. Wu et al., "Factors influencing the prevalence of anxiety and depression in patients with chronic musculoskeletal pain," World Latest Medicne Information (Electronic Version), vol. 19, no. 45, pp. 114-116, 2019.

[6] M. J. Cross and D. G. Hoy, "Musculoskeletal health conditions represent a global threat to healthy aging: a report for the 2015 world health organization world report on ageing and health," Gerontologist, vol. 56, no. 2, pp. S243-S255, 2016.

[7] Y. Lv, J. G. Cheng, B. F. Fa et al., "ICD-11 Chronic pain classification Chinese compiled version," Chinese Journal of Pain Medicine, vol. 24, no. 11, pp. 801-805, 2018.

[8] S. Epstein, E. H. Sparer, B. N. Tran et al., "Prevalence of workrelated musculoskeletal disorders among surgeons and interventionalists: a systematic review and meta-analysis," JAMA Surgery, vol. 153, no. 2, 2018.

[9] Access Economics, Painful Realities: The Economic Impact of Arthritis in Australia in 2007, Access Economics, Canberra, Australia, 2009.

[10] A. Tsang, M. Von Korff, L. Sing et al., "Common chronic pain conditions in developed and developing countries: gender and age differences and comorbidity with depression-anxiety disorders," The Journal of Pain, vol. 9, no. 10, pp. 883-891, 2008. 
[11] S. L. Brennan-Olsen, S. Cook, M. T. Leech et al., "Prevalence of arthritis according to age, sex and socioeconomic status in six low and middle income countries: analysis of data from the World Health Organization study on global ageing and adult health (SAGE) wave 1," BMC Musculoskeletal Disorders, vol. 18, no. 1, p. 271, 2017.

[12] K. Jordan, A. M. Clarke, D. P. Symmons et al., "Measuring disease prevalence: a comparison of musculoskeletal disease using four general practice consultation databases," British Journal of General Practice, vol. 57, no. 534, pp. 7-14, 2007.

[13] "A consensus among drug therapists for chronic musculoskeletal pain," Chinese Journal of Pain Medicine, vol. 24, no. 12, pp. 881-887, 2018.

[14] E. Yelin, S. Weinstein, and T. King, "An update on the burden of musculoskeletal diseases in the U.S," Seminars in Arthritis and Rheumatism, vol. 49, no. 1, pp. 1-2, 2019.

[15] S. J. Duffield, B. M. Ellis, N. Goodson et al., "The contribution of musculoskeletal disorders in multimorbidity: implications for practice and policy," Best Practice \& Research Clinical Rheumatology, vol. 31, no. 2, pp. 129-144, 2017.

[16] A. M. Briggs, A. D. Woolf, K. Dreinhöfer et al., "Reducing the global burden of musculoskeletal conditions," Bulletin of the World Health Organization, vol. 96, no. 5, pp. 366-368, 2018.

[17] E. Yelin, S. Weinstein, and T. King, "The burden of musculoskeletal diseases in the United States," Seminars in Arthritis and Rheumatism, vol. 46, no. 3, pp. 259-260, 2016.

[18] Z. B. Nie, Y. F. Rao, J. P. Chen, Z. Y. Feng, and B. F. Fan, "Expert consensus on therapy of chronic musculoskeletal pain (2018) interpretation: clinical application of antidepressants in chronic musculoskeletal pain," Chinese Journal of Pain Medicine, vol. 26, no. 3, pp. 169-173, 2020.

[19] C. Lee, C. Crawford, and S. Swann, "Multimodal, integrative therapies for the self- management of chronic pain symptoms," Pain Medicine, vol. 15, no. 1, pp. S76-S85, 2014.

[20] W. Weifen-Wu, A. Muheremu, and C. Chaohui, "Effectiveness of tai chi practice for non-specific chronic low back pain on retired athletes: a randomized controlled study," Journal of Musculoskeletal Pain, vol. 21, no. 1, 2013.

[21] C. Wang, C. H. Schmid, P. L. Hibberd et al., "Tai Chi is effective in treating knee osteoarthritis: a randomized controlled trial," Arthritis \& Rheumatism, vol. 61, no. 11, pp. 1545-1553, 2009.

[22] B. X. Liu, S. P. Chen, Y. D. Li et al., "The effect of the modified eighth section of eight-section brocade on osteoporosis in postmenopausal women: a prospective randomized trial," Medicine(Baltimore), vol. 94, no. 25, p. 991, 2015.

[23] Y. Deng, Z. Y. Chen, and Z. Q. Liu, "Effect of Yi Jin Jing exercise exercise on bone mineral density in elderly patients with primary osteoporosis," Chinese Rural Health Service Administration, vol. 35, no. 1, pp. 133-134, 2015.

[24] J. P. T. Higgins and S. Green, Cochrane Handbook for Systematic Reviews of Interventions: Online Version 5.1.0, The Cochrane Collaboration, London, UK, 2011.

[25] H.-J. Lee, H.-J. Park, Y. Chae et al., "Tai Chi Qigong for the quality of life of patients with knee osteoarthritis: a pilot, randomized, waiting list controlled trial," Clinical Rehabilitation, vol. 23, no. 6, pp. 504-511, 2009.

[26] J. Liu, A. Yeung, T. Xiao et al., "Chen-style tai chi for individuals (aged 50 years old or above) with chronic non-specific low back pain: a randomized controlled trial," International Journal of Environmental Research and Public Health, vol. 16, no. 3, p. 517, 2019.

[27] Q. Zhu, L. Huang, X. Wu et al., "Effects of Tai Ji Quan training on gait kinematics in older Chinese women with knee osteoarthritis: a randomized controlled trial," Journal of Sport and Health Science, vol. 5, no. 3, pp. 297-303, 2016.

[28] J.-M. Brismée, R. L. Paige, M.-C. Chyu et al., "Group and home-based tai chi in elderly subjects with knee osteoarthritis: a randomized controlled trial," Clinical Rehabilitation, vol. 21, no. 2, pp. 99-111, 2007.

[29] M. Fransen, L. Nairn, J. Winstanley, P. Lam, and J. Edmonds, "Physical activity for osteoarthritis management: a randomized controlled clinical trial evaluating hydrotherapy or Tai Chi classes," Arthritis \& Rheumatism, vol. 57, no. 3, pp. 407-414, 2007.

[30] M. Wortley, S. M. Zhang, P. Maxime et al., "Effects of resistance and Tai Ji training on mobility and symptoms in knee osteoarthritis patients," Journal of Sport and Health Science, vol. 2, no. 4, pp. 209-214, 2013.

[31] R. Song, E. O. Lee, P. Lam, and S. C. Bae, "Effects of tai chi exercise on pain, balance, muscle strength, and perceived difficulties in physical functioning in older women with osteoarthritis: a randomized clinical trial," The Journal of Rheumatology, vol. 30, no. 9, pp. 2039-2044, 2003.

[32] Y. F. Xu and L. Zhang, "Effectiveness of Tai Chi exercise on shoulder, neck and back pain among college students," Chinese Journal of School Health, vol. 40, no. 7, pp. 994-996, 2019.

[33] M. Y. Zhao, N. Li, C. Fan, and S. H. Yuan, "About the influence of Tai Chi push exercise combined with nutrition intervention to recover of patients with primary osteoporosis," Liaoning Sport Science and Technology, vol. 37, no. 3, pp. 44-46, 2015.

[34] Y. Z. Zheng, S. B. Zhou, and M. F. Li, "Observation on the therapeutic effect and mechanism of tai chi on patients with early knee osteoarthritis," Clinical Journal of Traditional Chinese Medicine, vol. 31, no. 5, pp. 970-973, 2019.

[35] Y. B. Zhou, Y. Q. Wang, and Y. F. Mo, "Treatment of 45 cases of primary osteoporosis with kidney yin deficiency syndrome by Tai Chi combined with Liuwei Dihuang decoction," Zhejiang Journal of Traditional Chinese Medicine, vol. 53, no. 4, p. 268, 2018.

[36] L. Xu and X. Z. Tang, "Effect of 24 style simplified Taijiquan on joint function of elderly patients with knee osteoarthritis," Journal of Nursing (China), vol. 23, no. 11, pp. 51-53, 2016.

[37] W. X. Fan, "Effect of long-term Tai Chi training cycle on moxibustion treatment of middle-aged and elderly patients with lumbar muscle strain," Chinese Journal of Gerontology, vol. 38, no. 5, pp. 1136-1137, 2018.

[38] X. Tong, R. J. Jin, P. Li, and L. Yin, "Clinical study on the treatment of chronic NLBP with Tai Chi Tui Shou," Chinese Manipulation and Rehabilitation Medicine, vol. 7, no. 6, pp. 25-27, 2016.

[39] B. An, K. Dai, Z. Zhu et al., "Baduanjin alleviates the symptoms of knee osteoarthritis," The Journal of Alternative and Complementary Medicine, vol. 14, no. 2, pp. 167-174, 2008.

[40] J. Ye, M. W. Simpson, Y. Liu et al., "The effects of baduanjin qigong on postural stability, proprioception, and symptoms of patients with knee osteoarthritis: a randomized controlled trial," Frontiers in Medicine, vol. 6, p. 307, 2019.

[41] Y. T. Yang, B. Hu, S. S. Li, G. Zuo, and Y. B. Lou, "Clinical study on characteristic triple therapy of muscles and bones combined with eight infantile finger loops and whorls in the treatment of chronic nonspecific low back pain," Henan Traditional Chinese Medicine, vol. 40, no. 10, pp. 1602-1605, 2020.

[42] J. Chen, "Clinical observation on the improvement of osteoporosis in postmenopausal women with traditional Chinese 
medicine diet and Ba Duan Jin exercise," Asia-Pacific Traditional Medicine, vol. 11, no. 7, pp. 104-105, 2015.

[43] Y. Chen, X. J. Xiong, H. Liu et al., "The effect of Ba Duan Jin exercise on pain and quality of life in patients with primary osteoporosis," China's Naturopathy, vol. 25, no. 3, pp. 18-19, 2017.

[44] X. L. Du and X. H. Zhao, "Clinical observation on the improvement of osteoporosis symptoms in postmenopausal women with traditional Chinese medicine diet and $\mathrm{Ba}$ duan Jin exercise," China Health Standard Management, vol. 5, no. 5, pp. 65-68, 2014.

[45] L. Li and Z. Y. Feng, "Clinical observation of treating chronic nonspecific low back pain with baduanjin combining sling exercise therapy," Rheumatism and Arthritis, vol. 4, no. 4, pp. 16-19, 2015.

[46] W. H. Liu, X. M. Shi, J. Yu et al., "Exercise therapy in prevention and treatment of navy personnel with chronic low back pain," Medical \& Pharmaceutical Journal of Chinese People's Liberation Army, vol. 30, no. 11, pp. 10-13, 2018.

[47] Y. Y. Liu, "The influence of special nursing training of eight infantile finger loops and whorls on peak torque and average power of knee joint in patients with knee osteoarthritis," Henan Traditional Chinese Medicine, vol. 38, no. 11, pp. 1779-1782, 2018.

[48] X. Wu, "Intermediate-frequency electric therapy combined with Ba Duan Jin exercise treating 52 cases of chronic low back pain in community," Chinese Medicine Modern Distance Education of China, vol. 10, no. 13, pp. 87-88, 2012.

[49] W. N. Wang and M. Zhao, "Clinical observation of warm acupuncture combined with Baduanjin in treating chronic lumbar muscle strain," China's Naturopathy, vol. 28, no. 4, pp. 38-40, 2020.

[50] J. Y. Wang, M. Xv, G. H. Liu, Y. S. Fan, and L. Yang, "Effects of traditional Chinese medicine therapy on lumbar muscle strain in athletes," Journal of Lanzhou University of Arts and Science, vol. 31, no. 6, pp. 103-107, 2017.

[51] J. Wan, Z. W. Liang, K. X. Sun, j. R. Wu, and X. D. Din, "Combination of Gongfa exercise Baduanjin and manipulation for the treatment of myofascial pain syndrome on shoulder and neck," Shanghai Journal of Traditional Chinese Medicine, vol. 47, no. 8, pp. 54-56, 2013.

[52] J. H. Su and Q. Deng, "Clinical study of eight trigrams boxing combined with anti-osteoporosis drugs treating postmenopausal osteoporosis," Acta Chinese Medicine and Pharmacology, vol. 46, no. 3, pp. 84-88, 2018.

[53] X. Y. Peng, Q. P. Li, and X. X. Li, "T the efficacy of Sitting Baduanjin exercise on lumbago and back pain of elderly patients with osteoporosis," Journal of Nursing Science, vol. 30, no. 21, pp. 4-6, 2015.

[54] H. Pang, B. Song, P. Zhao, and M. M. Lu, "Clinical research of rehabilitation effect of Ba duan Jin on lumbar disc herniation," Acta Chinese Medicine, vol. 28, no. 8, pp. 1241-1243, 2013.

[55] X. J. Zheng and X. Cheng, "Clinical observation of Ba duan Jin exercise combined with acupuncture in the treatment of knee osteoarthritis," Guangming Journal of Chinese Medicine, vol. 35, no. 20, pp. 3235-3237, 2020.

[56] H. X. Yang, "Study on rehabilitation effect of station pile work on chronic lumbar and knee joint strain of athletes in winter sports," Journal of Harbin Sport University, vol. 38, no. 5, pp. 1-7, 2020.

[57] Y. Y. Ye, X. H. Niu, Z. W. Qiu et al., "Effect of yijinjing on knee joint function in patients with knee osteoarthritis," Rheumatism and Arthritis, vol. 8, no. 10, pp. 19-23, 2019.
[58] J. Q. Zhao and H. Zhang, "Analysis on the application effect of Yi Jin jing exercise exercise combined with moxibustion in the treatment of elderly knee osteoarthritis," Health Horizon, vol. 12, p. 110, 2020.

[59] Y. Y. Zhao, Q. Y. Mi, J. H. Gang, H. M. Wang, and Y. Q. Cheng, "Clinical study on Yi Jin jing exercises combined with articular injection for early-to-mid osteoarthritis," Journal of New Chinese Medicine, vol. 52, no. 15, pp. 72-75, 2020.

[60] Y. Q. Zheng, F. H. Zhang, and L. Q. Zheng, "Analysis of the application effect of massage therapy muscle-bone strengthening exercise combined with moxibustion treatment in the treatment of senile knee osteoarthritis," Journal of Qiqihar Medical College, vol. 38, no. 5, pp. 522-524, 2017.

[61] Y. B. Wu and L. L. Lu, "Clinical study on treatment of intraarticular ozone with yijinjing training on knee osteoarthritis," Clinical Journal of Traditional Chinese Medicine, vol. 32, no. 8, pp. 1538-1541, 2020.

[62] J. H. Li, L. Gong, W. M. Hu, and M. Fang, "Clinical study on tuina plus yijinjing exercise in treating knee osteoarthritis," Liaoning Journal of Traditional Chinese Medicine, vol. 37, no. 9, pp. 1793-1795, 2010.

[63] T. J. Li, X. Li, W. H. Zhong, Z. H. Chen, and Q. K. Zheng, "Study on the effect of Yi Jin Jing exercise on liver and kidney deficiency syndrome in senile degenerative knee osteoarthritis," Guangming Journal of Chinese Medicine, vol. 33, no. 23, pp. 3456-3459, 2018.

[64] C. M. Xiao, J. J. Li, Y. Kang, and Y. C. Zhuang, "Follow-up of a Wuqinxi exercise at home programme to reduce pain and improve function for knee osteoarthritis in older people: a randomised controlled trial," Age and Ageing, vol. 50, no. 2, pp. 570-575, 2021.

[65] B. Y. Zhang, J. Xia, Y. R. Huang et al., "Effects of wuqinxi on treatment of fibromyalgia syndrome," Chinese Journal of Medicinal Guide, vol. 21, no. 4, pp. 217-221, 2019.

[66] F. Lei, J. T. Yan, Y. J. Cao, and G. Y. Zhang, "The effect of Wuqinxi exercise on mechanics characteristic of abdominal and back muscles and pain in patients with chronic nonspecific low back pain," Shanghai Journal of Traditional Chinese Medicine, vol. 49, no. 9, pp. 49-53, 2015.

[67] X. M. Ning, L. Wu, T. Wang, X. He, and Y. M. Yu, "Clinical study on five mimic- animal boxing combined with core muscular strength exercise for the treatment of nonspecific low back pain," The Journal of Traditional Chinese Orthopedics and Traumatology, vol. 27, no. 11, pp. 25-28, 2015.

[68] L. Z. Tang, C. H. Li, K. M. Zhang, A. T. Xiao, Z. Pan, and Y. Lin, "Clinical efficacy observation of massage combined with isokinetic training and wuqinxi on knee osteoarthritis," Journal of Hunan University of Traditional Chinese Medicine, vol. 39, no. 7, pp. 879-884, 2019.

[69] T. Ping and Y. P. Liao, "Effect of wuqinxi and zhanzhuang on knee flexor and extensor strength and WOMAC scores of female patients with KOA," Journal of Chengdu Sports Institute, vol. 40, no. 6, pp. 68-71, 2014.

[70] P. Huston and B. McFarlane, "Health benefits of tai chi: what is the evidence?" Canadian Family Physician, vol. 62, no. 11, pp. 881-890, 2016.

[71] X. Y. Li, J. Yun, J. He, H. Qin, D. Wang, and T. Li, “Metaanalysis of the intervention effect of Badanjin on patients with osteoporosis," China Osteoporosis Magazine, vol. 26, no. 1, pp. 37-43, 2020.

[72] X. Li, X. Wang, T. Li, J. He, and M. Hou, "A meta-analysis: therapeutic effect of tai chi on low back pain," Rehabilitation Medicine, vol. 27, no. 4, pp. 60-64, 2017. 
[73] Q. Q. Cao, L. L. Yang, W. L. Li et al., "Meta-analysis of Yi Jin jing exercise exercise in the prevention and treatment of elderly primary osteoporosis," World Chinese Medicine, vol. 13, no. 10, pp. 2647-2652, 2018.

[74] H. Li, D. Ge, S. Liu et al., "Baduanjin exercise for low back pain: a systematic review and meta-analysis," Complementary Therapies in Medicine, vol. 43, no. 43, pp. 109-116, 2019.

[75] M. W. Zhou, S. W. Yue, C. Q. He et al., "Rehabilitation treatment of lumbar disc herniation," Journal of Rehabilitation Medicine, China, vol. 32, no. 2, pp. 129-135, 2017.

[76] W. J. Liu and J. Y. Hao, "Systematic evaluation and metaanalysis of Tai Chi for joint pain and stiffness and dysfunction in patients with bone joints," Chinese Journal of Gerontology, vol. 40, no. 16, pp. 3471-3475, 2020.

[77] H. Xie, J. K. Pan, K. H. Hong, H. T. Huang, H. D. Liang, and J. Liu, "Taijiquan for osteoarthritis: a systematic review and meta-analysis," Chinese Journal of Traditional Chinese Medicine, vol. 31, no. 5, pp. 1863-1867, 2016.

[78] Y. Xie, G. Wei, Y. K. Guo et al., "Evaluation and meta-analysis of Tai Chi treatment of knee osteoarthritis," Chinese Journal of Rehabilitation Medicine, vol. 30, no. 5, pp. 483-489, 2015.

[79] X. W. Han, "Talk about the sports characteristics and fitness function of Tai Chi," Business Culture, vol. 11, p. 211, 2011.

[80] Z. G. Huang, Y. H. Feng, Y. H. Li, and C. S. Lv, "Systematic review and meta-analysis: Tai Chi for preventing falls in older adults," BMJ Open, vol. 7, no. 2, Article ID e013661, 2017.

[81] Y. N. Hu, Y. J. Chung, H. K. Yu et al., "Effect of tai chi exercise on fall prevention in older adults: systematic review and metaanalysis of randomized controlled trials," International Journal of Gerontology, vol. 10, no. 3, 2016.

[82] P. X. Li, "Discussion on the motion properties of the Yi Jin jing exercise exercise," Shaolin and Tai Chi, vol. 3, p. 45, 2009.

[83] S. D. Dou, R. X. Xu, N. X. Wu, and Y. Y. Ye, "Research of modern application of health qigong yijinjing exercise," Chinese Archives of Traditional Chinese Medicine, vol. 35, no. 5, pp. 1083-1085, 2017.

[84] W. M. Hu, L. Gong, Y. M. Qian, and H. Hu, "Tuina yijinjing gong practice improves the knee muscle strength of the elderly," Chinese Journal of Sports Medicine, vol. 32, no. 9, pp. 775-779, 2013.

[85] X. Y. Ren and X. F. Yang, "A review and prospect of the research on Wu Qin Xi exercise in the past forty years," Journal of Ezhou University, vol. 27, no. 6, pp. 92-94, 2020. 